\title{
On the Impact of (II)literacy on L2 Italian Acquisition of Unaccompanied Foreign Minors
}

\author{
Castrenze Nigrelli \\ Università degli Studi di Palermo,viale delle Scienze, 90128, Palermo, Italy \\ castrenze.nigrellieunipa.it
}

\begin{abstract}
The aim of the paper is to analyse the interlanguage of L2 Italian learners with the same L1 but different levels of education. The learners belong to the "unaccompanied foreign minors" category, whose linguistic profile is characterised by the frequent coexistence of a multilingual ability and a very low, or zero, level of education. Focusing on the acquisition of verb inflectional morphology and on phraseological units as well, the comparison of learners' varieties aims to show that several differences depend on the only parameter that differentiates them, namely literacy vs. illiteracy in L1.
\end{abstract}

Keywords: Second Language Acquisition, L2 Italian, Unaccompanied Foreign Minors.

\section{Introduction}

\subsection{Unaccompanied Foreign Minors: Multilingualism and Illiteracy}

Minors who are not Italian citizens, nor asylum seekers, and are in Italy without adults who have legal responsibility belong to the category of "unaccompanied foreign minors" (henceforth UFMs). The city of Palermo is a multilingual environment that hosts a considerable number of migrants from different places, and UFMs make Italian classrooms linguistically mixed. UFMs are a heterogeneous and peculiar sociolinguistic category (see [1]). They belong to very different cultures, and come from different multilingual areas (especially from Africa and Asia). UFMs are characterised by an extraordinary multilingual ability and by a low level of education. Often, UFMs have, in addition to their own L1, some competence in one or more languages spoken in the place of origin, as well as other languages they came into contact with during the long stops of their travels to Italy. At the same time, their level of education is mostly low, or very low (less than 5 years of school), or even non-existent. They are, ultimately, both multilingual and functionally or completely illiterate.

The above specificity makes these learners' profile peculiar and unprecedented. In the absence of solid previous schooling, competence in languages (including L1) is very often limited to oral competence alone, and this has significant repercussions on second-language acquisition and, therefore, on social inclusion (see [2]-[3]). 
UFMs have a certain ability to manage oral texts, but a low familiarity with written texts. This has inevitable consequences in terms of meta-textual and meta-linguistic reflection, which affect the process of acquiring an L2. The problem is even more serious for the completely illiterates UFMs. A competence, even partial, in writing and reading has an important impact on the mental processes of the individual (see [4]-[5]). Someone who knows how to write usually calls to mind the graphic images of the words and this makes him more able not only to memorize, but also to analyse, since they are more used to breaking down the phonic continuum into words (and the words, in turn, into smaller units). His brain is, therefore, more suited to metalinguistic reflection and to processes of abstraction, generalization and modelling, while that of the illiterate is anchored to mechanisms that are purely pragmatic and semantic (see [6]).

To evaluate the impact of (il)literacy on the acquisition of an L2, with particular reference to verbs and verbal categories in Italian, the paper analyses the interlanguage (see [7]) of two analogous UFM learners in the sociolinguistic profile, but, one is completely illiterate in his own L1, while the other has a low (but not very low) level of schooling. The corpus is based on their oral productions (interviews).

\section{$2 \quad$ Methodology}

\subsection{Sample Choice and Learners' Profile}

The study aims to verify to what extent any divergences in the learners' varieties are to be attributed to a given parameter, i.e. (il)literacy in L1, which it is therefore sought to isolate, by a suitable sample choice. The learners are in fact both UFMs who arrived in Italy a few months ago initially originating from Gambia, with Mandinka as L1 and English as L2 (official language in Gambia). Both learners are at the end of a course in L2 Italian for absolute beginners (about 40 hours). Sociolinguistically, the element of distinction between the two learners is (il)literacy in L1. The learner S.D. has been in Italy for 3 months, studied in Gambia for 9 years and is, therefore, literate in his L1 despite having a low level of schooling. The learner M.S. has been in Italy for 7 months, never went to school in his country of origin and he was illiterate when arrived in Italy. As shown by the interview, S.D. is more widely multilingual, since he seems to know Wolof as L2 and has a certain competence of Joula and Fula.

Mandinka is a language of the Mande group (Niger-Congo sub-family; NigerKordofanian family), spoken in a vast area of West Africa. In Mandinka, temporal, aspectual, and modal information is conveyed by affixes. Mandinka presents an unmarked syntactic order of the SOV type, and a variable order modifier/name follow-

ing the scheme: Gen/N, Poss/N, N/A, DimN/NDim, NPlur (for further details, see [8]).

\subsection{Method of Data Collection and Analysis}

Data consists of oral texts produced by the two above learners through semistructured face-to-face interviews (see Table 1, Appendix). The conversation started 
from a list of questions prepared by the native interviewer and concerning aspects of the informant's personal and everyday life as well as his experiences in linguistic matters. To stimulate the informant to use certain linguistic structures and to better investigate the acquisition stage of the verbal categories, several specific questions were also chosen by the interviewer.

From the perspective of conversation analysis, the native-non-native interaction is considered as prototypically asymmetric [9]. The interviews were audio-video recorded and subsequently transcribed in accordance with the transcription method of conversation analysis. However, the presence of recording system has further inhibited informants. This contributed to raise Krashen's affective filter, partially compromising the spontaneity of the performance [10]. Furthermore, the way the interviewer deals with the situation could play a role due to the linguistic and emotional fragility of the informants. In some cases, the interviewer's reformulations resolves the interviewee's impasse too quickly and, if on the one hand this makes him feel more at ease, on the other hand it prevents the opportunity to find more data. Through a careful examination of learner's oral productions, the analysis aims to establish both the stage of acquisition they are in and the role played by (il)literacy, with reference to the acquisition of the verb inflectional morphology and to phraseology.

\section{$3 \quad$ Analysis}

\subsection{Analysis of the Variety of M.S.}

The presence of different verbal forms in M.S. learning variety shows that he somehow distinguishes the verb as an entity. Most verbs occur in a "base" form (see [11]): most of the time the learner overextends the use of the third person of the present indicative, other times the second person (probably basing on that of the input in the question), and in others the infinitive (e.g. Io comincia; io vai a Mondello; non studiare Gambia). Among the base forms, the use of the infinitive can usually depend on two factors: either the input to which the learner is most frequently exposed, especially if the natives with whom he is in contact use ultra-simplified varieties (foreigner talk), or the particular context of non-actuality, non-reality of the event (such as in this case). In the context of interaction, the phrase "non studiare Gambia" actually means "non ho studiato in Gambia" ("I did not study in Gambia") and therefore refers to an event that is perfective and non-actual: through overextension, the functional use of the infinitive form of the verb helps the learner to express a distinction which is aspectual (i.e. perfective vs. imperfective). The use of person markers in the present indicative is sporadic and the learner is still completely uncertain, as evidenced by the presence of several reformulations (e.g. "a mare: giaoca: | gioco football" or in "io non lo so", then reformulated as "non lo sa"). The correct use in "non lo so" could also depend on a memorization of said formula - generally, occurring frequently in the input - of which the learner is not fully aware. There are also other examples of formulas, e.g. "come stai?" or the request for help in the quite uncertain phrase "come mi tiam que?" (which would be "come si chiama questo?" "How do you say this?"). In several cases the learner simplifies the statement by omitting the copula, as in " $\mathrm{Pa}$ - 
lermo buono, tutti buono, Mondello bravissimo". In other cases, he tries to make up for it through extra-linguistic elements (gestures and mimicry), like when he says Casa nodding with his head to indicate "staying", or through leaning on his L2 English, like when he says "to:: ///" miming the action of swimming, which references back to the English infinitive form with the particle to.

The only isolated example of an aspectual marker is in the past participle of capire "to understand", e.g. "io no capito italiano". According to acquisition stages, said past participle marker -to is the first aspectual marker learnt, and, in turn, [auxiliary + past participle] constitutes an Italian tense conveying perfective aspect (i.e. passato prossimo), which is learnt successively. Furthermore, in the last example, the verb in question (i.e. capire) also represents a prototypical case where learners usually start to use the aspectual marker -to, due to actional features (Aktionsart) of the verb, namely telicity, which makes telic verbs semantically more compatible with expressing perfective aspect (see [12]-[13]).

\subsection{Analysis of the Interlanguage of S.D.}

The analysis of S.D. learning variety can identify some features common to the variety of M.S, despite there being several significant differences. Also S.D. seems to distinguish verbal entities within the sentence, although he is still lacking in terms of inflectional morphology. Even in his production there are several occurrences in which the verb occurs in the base form. However, the overextension concerns only the infinitive form, except for two occurrences of the third person, which are actually reformulated immediately ("io non è" > "non ho"). In fact, in "io / tre lingue / parlare tre lingue", the use of the infinitive form overextends into present indicative contexts, while in the other three occurrences ("io andare scuola, giocare calcio, scuola giocare e basta") seems to make up for the lack of the imperfect, in its value of imperfective past, to express habitual actions in the past (on verbal aspect in Italian, see, among others [14]). Also S.D. omits the copula, as in "Palermo:: bella, tutti:: bravo", although less often than M.S.

S.D. is more at ease than M.S. in using of the inflectional markers of first person. In fact, the first person of the indicative present fully represents the most frequent verbal form in its variety, as it is evidenced by several examples: "io sono gambiano, ho novo ani, io ho / fratello: picolo", "mi piace, io mi piace capoeira, mi facio capoeira".

\subsection{Comparison of Learning Varieties}

The characteristics of the learners' interlanguages analysed above allow to consider their varieties as certainly basic varieties, as it was reasonable to predict. According to Klein \& Perdue (see [11), both learners are in fact in that non-inflectional initial phase of the second language acquisition process. Both seems to be aware of the entity of verb and distinguish it from noun. In some cases, they also seem to have some aware-

ness of the argumental structure of the verbs they use. Regarding the expression of the verbal categories of tense and aspect, the functional role of both is made up exclusive- 
ly for the indicative present or the infinitive form: both learners in fact present the typical base forms, overextending the infinitive or the second or third person of the indicative present to express the past as well as a perfective aspect. The only form of morphologically overt aspectual opposition is isolated: this is the past participle of capire, which M.S. uses only once. Both learners do not have the means to express the future and implement avoidance strategies (see questions that close interviews). They tend to omit the copula and do not yet have full awareness of the markers of firstperson of the present indicative, although with significant differences between the two: S.D. has in fact several occurrences and seems clearly more at ease.

Available data already allows noting a certain gap between the performances and to consider that, at least to a certain extent, depending on the (il)literacy in L1 parameter. The schooled learner (S.D.), despite being in Italy for less time (3 months vs. 7) shows a greater skill in oral interaction, a greater communicative efficacy, greater accuracy and fluency. He understands the questions without the difficulties shown by M.S., he also responds more promptly, he takes fewer breaks, and without requesting any help. Moreover, he never produces bilingual statements, nor does it rely on English (second language for both learners) to make up for lexical or syntactical gaps, as M.S. does. Also, the dependence on the context and on common knowledge is mini-

$\mathrm{mal}$, if not null, with respect to the frequent use of the gestures or lexical strategies of M.S. Furthermore, in the acquisition of verbal morphology, a considerable gap - for accuracy and number of occurrences - is shown in the use of the markers of firstperson that M.S. uses well only in some formulaic statements like non lo so. Finally, the use of the basic forms of S.D. (only the infinitive) is also limited to the narrative context that would have required the expression of the past (with a perfective and imperfective aspect).

\section{Conclusions}

From the strategies implemented by the two learners in the interviews and the characteristics of their interlanguage, it was possible to place them within the basic acquisition phase. Although the sociolinguistic profile and the learning context of the learners are close similar, the differences between their varieties are not without importance, though mostly blurred. To a certain extent, the differences found in the analysis of their productions seem to depend on that S.D. has a certain level of education and proficiency in writing skills, while M.S. is completely illiterate. Despite the same length of learning course (about 40 for both), the schooled learner had an exposure to the target language less than illiterate one ( 3 vs. 7 months). Besides his larger multilingual competence, the positive differences in the performance of the schooled learner can be reasonably ascribed to literacy, which substantially distinguished the sociolinguistic profiles. 


\section{Annex}

Table 1. Interviews of M.S. and S.D.

\begin{tabular}{|c|c|c|c|}
\hline I.1: Ciao M.! & M.S.2: Ciao & I.1: Ciao S.! & S.D.2: Ciao \\
\hline I.3: Ciao come stai? & M.S.4: Bene e tu? & I.3: Come stai? & S.D.4: Bene \\
\hline I.5: Io tutto bene grazie & M.S.6: $S i$ & $\begin{array}{l}\text { I.5: Allora / ehm:: da quanto } \\
\text { tempo sei a Palermo? }\end{array}$ & $\begin{array}{l}\text { S.D.6: Ehm::.: due: } \\
\text { tresetres+ |due? / ehm: } \\
\text { a: trese }\end{array}$ \\
\hline $\begin{array}{l}\text { I.7: E:: ti faccio qualche } \\
\text { domanda: / ehm:: da quanto } \\
\text { tempo sei a Palermo? }\end{array}$ & M.S.8: Io? & I.7: Tre mesi? & $\begin{array}{l}\text { S.D.8: Tre mesi sì } \\
\text { ((nodding his head }))\end{array}$ \\
\hline I.9: $S i$ & $\begin{array}{l}\text { M.S.10: Forsa:: due tre ann+ }((\text { making } \\
\text { the number three with his fingers }))\end{array}$ & $\begin{array}{l}\text { I.9: Ok / ehm:: ti piace questa } \\
\text { citta?? }\end{array}$ & S.D.10: Sì sì mi piace \\
\hline I.11: Tre an[ni] & $\begin{array}{l}\text { M.S.12: [Si] tre anni ((making the } \\
\text { number three with his fingers)) } \\
((\text { nodding his head }))\end{array}$ & I.11: Perché? & $\begin{array}{l}\text { S.D.12: } \text { E:: perché: } \\
\text { Palermo:: bella / sì::// } \\
e:: x x((\text { smiling })) \text { se: } e: \\
x x / / \text { belissimo }\end{array}$ \\
\hline $\begin{array}{l}\text { I.13: Ok // ehm:: ti piace } \\
\text { Palermo? }\end{array}$ & $\begin{array}{l}\text { M.S.14: Sì ((in a low voice)) ((nodding } \\
\text { his head)) }\end{array}$ & I.13: Uhm & S.D.14: Ehm:: buono \\
\hline $\begin{array}{l}\text { I.15: Perché? Che cosa ti piace } \\
\text { di Palermo? }\end{array}$ & $\begin{array}{l}\text { M.S.16: Palermo perché: Palermo } \\
\text { buono / io / comincia / buono // tutti } \\
\text { buono ((nodding his head)) }\end{array}$ & I.15: $S i$ & $\begin{array}{l}\text { S.D.16: } O k / / \text { tuti:: } \\
\text { bravo }\end{array}$ \\
\hline $\begin{array}{l}\text { I.17: Mhm? Ti piacciono le } \\
\text { persone? }\end{array}$ & $\begin{array}{l}\text { M.S.18: Si ((nodding his head)) ((in a } \\
\text { low voice)) }\end{array}$ & $\begin{array}{l}\text { I.17: Ti piacciono le persone di } \\
\text { questa città? }\end{array}$ & $\begin{array}{l}\text { S.D.18: Si sì me piace } \\
\text { ((nodding his head)) }\end{array}$ \\
\hline I.19: a Palermo? & $\begin{array}{l}\text { M.S.20: Sì ((nodding his head)) ((in a } \\
\text { low voice)) }\end{array}$ & $\begin{array}{l}\text { I.19: Uhm ok / ehm:: e:: di quale } \\
\text { nazionalità sei tu? }\end{array}$ & $\begin{array}{l}\text { S.D.20: Io Gambia / } \\
\text { Ga+ } \| \text { io sono } \\
\text { gambiano }\end{array}$ \\
\hline $\begin{array}{l}\text { I.21: E la città? Che cosa ti } \\
\text { piace della città? }\end{array}$ & $\begin{array}{l}\text { M.S.22: La sità // } \sum \text { no: non lo so } \\
\text { ((shaking his head }) \text { ) }\end{array}$ & $\begin{array}{l}\text { I.21: Ok ehm::: e che lingua:: } \\
\text { parlavi in Gambia? }\end{array}$ & S.D.22: Mandinka \\
\hline $\begin{array}{l}\text { I.23: Mhm ho capito / e:: d da } \\
\text { quale paese provieni? Qual è il } \\
\text { tuo paese di origine? }\end{array}$ & M.S.24: Io? $x x$ & I.23: $O k / a$ casa? & S.D.24: $A$ casa sì \\
\hline I.25: Gambia? & M.S.26: Sì Gambia Gambia & $\begin{array}{l}\text { I.25: Ok e altre lingue? Che altre } \\
\text { lingue conosci? }\end{array}$ & S.D.26: Cosa? \\
\hline I.27: Quindi sei gambiano & M.S.28: Sì gambian & $\begin{array}{l}\text { I.27: Che altre lingue conosci? } \\
\text { Conosci altre lingue? }\end{array}$ & S.D.28: $I o ?$ \\
\hline $\begin{array}{l}\text { I.29: Ok ok // e }: * \text { in Gambia } \\
\text { quale lingua parlavi a casa? }\end{array}$ & M.S.30: Mandinka. & I.29: $S i$ & S.D.30: Io Gambio: \\
\hline I.31: Mandinka. & M.S.32: Si ((nodding his head)) & $\begin{array}{l}\text { I.31: A parte mandinka, conosci } \\
\text { altre lingue? }\end{array}$ & $\begin{array}{l}\text { S.D.32:Mandinka, } \\
\text { wolof }=\end{array}$ \\
\hline $\begin{array}{l}\text { I.33: Ok/ e conosci anche altre } \\
\text { lingue? }\end{array}$ & M.S.34: Ingl || scuola inglis+ & I.33: Uhm & S.D.34: $=$ Inglis $=$ \\
\hline I.35: Ah. Hai studiato a scuola? & $\begin{array}{l}\text { M.S.36: Gambia ((making the "out" sign } \\
\text { with his hand })) \text { In Gambia? }\end{array}$ & I.35: $A h a h$ & S.D.36: $=$ Joula $=$ \\
\hline I.37: In Gambia? & M.S.38: No no no ((shaking his head)) & I.37: $S i$ & S.D.38: = Fula \\
\hline I.39: $A h /[o k]$ & $\begin{array}{l}\text { M.S. } 40: \text { [non studiare] Gambia ((in a } \\
\text { low voice)) }\end{array}$ & I.39: $M i::$ & S.D.40:Cingue lingue \\
\hline $\begin{array}{l}\text { I. } 41: \text { Non } s+\text { non sei andato a } \\
\text { scuola? }\end{array}$ & M.S.42: No no no ((shaking his head)) & I.41: Tantissime lingue! & $\begin{array}{l}\text { S.D. } 42 \text { : No io / tre } \\
\text { lingue / parlare tre } \\
\text { lingue } \\
\text { bravo! }\end{array}$ \\
\hline $\begin{array}{l}\text { I.43: Ok / ehm: e invece::mhm:: } \\
\text { da quanto tempo studi } \\
\text { l'italiano? }\end{array}$ & M.S.44: Taliano ((nodding his head)) & I.43: Ok ne parli tre & S.D.44: $S i$ \\
\hline I.45: L'hai studiato qua? & M.S.46: Si ((nodding his head)) & I.45: Però / ne [conosci cinque] & $\begin{array}{l}\text { S.D.46: [Cingue } \\
\text { lingue] si }\end{array}$ \\
\hline I.47: $o$ anche [prima]? & $\begin{array}{l}\text { M.S.48: [No] qua/ Palermo qua } \\
\text { ((making the "stay" sign with his head }) \text { ) }\end{array}$ & I.47: Ok/quali lingue parli? & $\begin{array}{l}\text { S.D.48: Io: / mandinka } \\
=\end{array}$ \\
\hline I.49: Solo a Palermo? & M.S.50: $S i$ & & \\
\hline $\begin{array}{l}\text { I.51: Ok / e per quanto tempo? } \\
\text { Quanti mesi? }\end{array}$ & $\begin{array}{l}\text { M.S.52: In Palermo? I// No [no] } \\
\text { ((shaking his head }))\end{array}$ & I.49: $S i$ & $\begin{array}{l}\text { S.D. } 50:=\text { Wolof } / \\
\text { inglese }\end{array}$ \\
\hline $\begin{array}{l}\text { I.53: [No] l'italiano: il corso di } \\
\text { italiano }\end{array}$ & M.S.54: [Si] & & \\
\hline $\begin{array}{l}\text { I.55: [Per quanti] mesi hai } \\
\text { studiato? }\end{array}$ & M.S.56: Palermo qua? & I.51: $O k=$ & $\begin{array}{l}\text { S.D.52: Si ((a voce } \\
\text { bassa)) }\end{array}$ \\
\hline I.57: $S i$ & M.S.58: Nsa: // $\Sigma$ no no: ((making a sign & I.53: $=O k /$ ehm $\because: e \cos a t i$ & S.D.54: Che cosa? \\
\hline
\end{tabular}




\begin{tabular}{|c|c|c|c|}
\hline & with his fingers)) ((shaking his head)) & piace fare nel tempo libero? & \\
\hline I.59: Non:: non ti ricor[di:] & M.S.60: [No] non [ti ri+] ((smiling)) & $\begin{array}{l}\text { I.55: Nel tempo libero: / quando } \\
\text { non sei a scuola }\end{array}$ & $\begin{array}{l}\text { S.D.56: Io? Ehm } \cdots \text { ho } \\
\text { novo ani } \mid \text { novo ano }\end{array}$ \\
\hline $\begin{array}{l}\text { I.61: [ok] ehm:: volevo } \\
\text { chiederti:: e nel tempo libero } \\
\text { cosa ti piace fare? }\end{array}$ & $\begin{array}{l}\text { M.S.62: IIII Io no: I/I ((making a sign } \\
\text { with his fingers)) (( smiling)) capito } \\
\text { itali[ano] ( }(\text { making a sign with his } \\
\text { fingers }))=\end{array}$ & $\begin{array}{l}\text { I. } 57: \text { No / ti chiedo: } e: \text { quando } \\
\text { non vieni a scuo:la: }: \ldots=e\end{array}$ & S.D.58: Inglese \\
\hline I.63: $[o k]$ & M.S.64: = Bela [poco] & $\begin{array}{l}\text { I.59: No no: e:: cosa cosa fai } \\
\text { durante la giornata? cosa ti } \\
\text { piace fare? }\end{array}$ & S.D.60: $E::$ \\
\hline $\begin{array}{l}\text { I.65: [Si si] ti rifaccio la } \\
\text { domanda? }\end{array}$ & M.S.66: ((nodding his head)) & $\begin{array}{l}\text { I.61: Ehm::: vai a gioca::re:: } \\
o: \because \ldots\end{array}$ & $\begin{array}{l}\text { S.D.62: Sì sì sì } \\
\text { ((smiling)) io: } \text { mi piace } \\
\text { capoeira }\end{array}$ \\
\hline $\begin{array}{l}\text { I.67: Cosa ti piace quando sei } \\
\text { libero? Quando hai tempo } \\
\text { libero? }\end{array}$ & M.S.68: ncas+ & I.63: $A h$ & $\begin{array}{l}\text { S.D.64: Si sì mi facio / } \\
\text { mi facio capoeira }\end{array}$ \\
\hline I.69: $E::$ a casa $::$ o fuori $::$ & M.S.70: $\mathrm{Si}\left[\mathrm{cas}^{+}\right]$ & I.65: Ah bello! & S.D.66: $S i$ \\
\hline $\begin{array}{l}\text { I.71: Quando non sei a scuola / } \\
\text { cosa fai? }\end{array}$ & $\begin{array}{l}\text { M.S.72: Casa ((making the "stay" sign } \\
\text { with his head }))\end{array}$ & $\begin{array}{l}\text { I.67: E:: e in Gambia: sei stato a } \\
\text { scuola? }\end{array}$ & S.D.68: $\mathrm{Si}$ \\
\hline I.73: Sei \| Stai a casa? & M.S.74: ((nodding his head)) & $\begin{array}{l}\text { I.69: Quanti:: quanti anni hai } \\
\text { studiato? }\end{array}$ & $\begin{array}{l}\text { S.D. } 70: x x \text { nov } \mid \text { novo } \\
\text { ani } \mid \text { ano }\end{array}$ \\
\hline $\begin{array}{l}\text { I.75: Ok / ehm:*: vai fuori } \\
\text { anche? Oppure stai sempre a } \\
\text { casa? }\end{array}$ & $\begin{array}{l}\text { M.S.76: Fori / quan+fori io vai a } \\
\text { Mondello }\end{array}$ & I.71: Per nove anni? & S.D.72: $S i$ \\
\hline I.77: [Mhm:] & $\begin{array}{l}\text { M.S.78: [Si] Mondello bravissimo! } \\
((\text { smiling }))\end{array}$ & $\begin{array}{l}\text { I.73: Ok ehm: }: \text { raccontami: che } \\
\text { cosa facevi in Gambia? }\end{array}$ & S.D.74: $I o ?$ \\
\hline I.79: $[A h]$ & M.S.80: Sì ((smiling)) & I.75: Si / nella vita & $\begin{array}{l}\text { S.D.76: Io andare } \\
\text { scuola }=\end{array}$ \\
\hline I.81: Bello / ti piace? & M.S.82: $S i$ & I.77: $S i$ & $\begin{array}{l}\text { S.D.78: }=\text { E }:: \text { giocare } \\
\text { calcio }= \\
\text { S.D. } 80:=E \text { che }: \text { io }\end{array}$ \\
\hline $\begin{array}{l}\text { I.83: } E \text { che cosa fai a } \\
\text { Mondello? }\end{array}$ & $\begin{array}{l}\text { M.S.84: Perché: // caldissimo xx va a } \\
\text { Mondello: }=\end{array}$ & I.79: $S i$ & $\begin{array}{l}\text { non è non è: | ho:: } e: \\
\text { la+ li+ -che cosa- } \\
\text { lavoro in Gambia no: / } \\
\text { scuola:: giocare: e } \\
\text { basta }\end{array}$ \\
\hline I.85: $S i$ & $\begin{array}{l}\text { M.S.86: = to:: III ((miming the action of } \\
\text { swimming }) \text { [-come mi tiamque?-] }\end{array}$ & I.81: Ho capito $=$ & S.D.82: $S i$ \\
\hline I.87: [vai a nuotare?] A mare? & M.S.88: A mare si & $\begin{array}{l}\text { I.83: = Ho capito / ehm::: } \\
\text { quando sarai grande } \mid \text { quando } \\
\text { sarai più [grande?] = }\end{array}$ & S.D.84: [Io:] \\
\hline I.89: Vai a mare /[ho capito] & $\begin{array}{l}\text { M.S.90: [Si] ((nodding his head)) / xx a } \\
\text { mare: giaoca: | gioco football }\end{array}$ & I.85: = Cosa farai $?$ & $\begin{array}{l}\text { S.D.86: Io: ho / } \\
\text { fratello: picolo uno / } \\
\text { grandi uno }\end{array}$ \\
\hline I.91: $A h ![E::]$ & M.S.92: [Si] & $\begin{array}{l}\text { I.87: Si / E: vuoi andare / da } \\
\text { loro? }\end{array}$ & S.D.88: Sì sì \\
\hline I.93: Con::: || giochi come? & $\begin{array}{l}\text { M.S.94: Qua ((making the "out" sign } \\
\text { with his hand)) // Palermo qua // Io } \\
\text { comincia: //I I// Io// }\end{array}$ & $\begin{array}{l}\text { I.89: Ok/ok/S. e:: ti ringrazio / } \\
\text { ciao. }\end{array}$ & S.D.90: Ciao / grasi \\
\hline I.95: Qua / vicino alla stazione? & $\begin{array}{l}\text { M.S.96: Firi ((making a circle with his } \\
\text { hands }))\end{array}$ & & \\
\hline I.97: Alforo? & M.S.98: Foro sì ((nodding his head)) & & \\
\hline I.99: Foro italico? & M.S.100: $S i$ & & \\
\hline I.101: Ah: e come giocate? & M.S.102: Tuti comti & & \\
\hline $\begin{array}{l}\text { I.103: No: che / che gioco? A } \\
\text { che gioco giocate? }\end{array}$ & M.S.104: Io? ((indicating himself)) & & \\
\hline I.105: $S i$ & $\begin{array}{l}\text { M.S.106: *Goalkeeper ((miming a } \\
\text { goalkeeper }))\end{array}$ & & \\
\hline I.107: $A h:: !$ & M.S.108: $[S i]$ & & \\
\hline I.109: [E::::] goalkeeper! & M.S.110: sì [goalkeep+] ((smiling)) & & \\
\hline $\begin{array}{l}\text { I.111: [Fai] fai } \mid \text { quindi giocate } \\
\text { a pallone, a calcio? }\end{array}$ & $\begin{array}{l}\text { M.S.112: Si si ((smiling)) ((nodding his } \\
\text { head)) }\end{array}$ & & \\
\hline $\begin{array}{l}\text { I.113: E tu fai il portiere: } \\
\text { I.115: Ok ok // Ehm:*: un'altra }\end{array}$ & M.S.114: Sì: ((smiling)) & & \\
\hline $\begin{array}{l}\text { cosa } / \text { e }::: \text { quando sarai più } \\
\text { grande } ?=\end{array}$ & M.S.116: $M h m$ & & \\
\hline I.117: = Cosa vorrai fare? & M.S.118: /// & & \\
\hline
\end{tabular}




\begin{tabular}{|c|c|}
\hline $\begin{array}{l}\text { I.119: Fra un anno:: fra due } \\
\text { anni:: // che cosa ti piacerebbe } \\
\text { fare? Cosa vorrai fare? }\end{array}$ & M.S.120: Sa due a+ \\
\hline I.121: Fra due anni: & M.S.122: $M h m$ \\
\hline $\begin{array}{l}\text { I.123: Quando sarai più } \\
\text { grande: / }\end{array}$ & M.S.124: $M h m$ \\
\hline $\begin{array}{l}\text { I.125: Cosa }:: \text { ti piacerebbe } \\
\text { fare? }\end{array}$ & $\begin{array}{l}\text { M.S.126: /// No io non lo so ((shaking his } \\
\text { head)) }\end{array}$ \\
\hline I.127: Non lo sai? & M.S.128: No no non lo sa \\
\hline $\begin{array}{l}\text { I.129: } O k / v a \text { bene / ok } M \text {. } \\
\text { grazie }\end{array}$ & M.S.130: Prego \\
\hline
\end{tabular}

\section{References}

1. Barone, L.: L'accoglienza dei minori stranieri non accompagnati. Tra norma giuridica e agire sociale. Key Editore (2016).

2. Demetrio, D., Moroni, F.: Alfabetizzazione degli adulti: teoria, programmazione, metodi. Editrice sindacale italiana, Roma (1980).

3. Watson, J. A.: Cautionary tales of LESLLA Students in the High School Classroom. In: Vinogradov, P., Bigelow, M. (eds.), Low Educated Second Language and Literacy Acquisition - Proceedings of the 7th Symposium, Minneapolis, Minnesota, USA, pp. 203-234. (2011).

4. Luria, A. R.: Cognitive development: Its cultural and social foundations. Harvard University Press, Cambridge (1976).

5. Ong, W.: Orality and Literacy. Methuen, London-New York (1982).

6. Minuz, F.: Italiano L2 e alfabetizzazione in età adulta. Carocci, Roma (2005).

7. Selinker, L.: Interlanguage. International Review of Applied Linguistics in Language Teaching 10(3), 209-231 (1972).

8. Banfi, E., Grandi, N. (eds.): Le lingue extraeuropee: Asia e Africa. Carocci, Roma (2008).

9. Orletti, F.: La conversazione diseguale: potere e interazione. Carocci, Roma (2000).

10. Krashen, S.: Second language acquisition and second language learning. Pergamon, Oxford (1981).

11. Klein, W., Perdue, C.: The Basic Variety (or: Could's Natural languages be much simpler?). Second Language Research 13, 301-347 (1997).

12. Vendler, Z.: Linguistics in Philosophy. Cornell University Press, Ithaca (1967).

13. Giacalone Ramat, A. (ed.): Verso l'italiano. Percorsi e strategie di acquisizione. Caroccci, Roma (2003).

14. Bertinetto, P. M.: Tempo, aspetto e azione nel verbo italiano: il sistema dell'indicativo. Accademia Della Crusca, Firenze (1986). 